\title{
STRATEGIC ANALYSIS MODEL OF DETERMINANT IN MAKING COMPETITIVINESS \\ (Study of tourism sector in Bandar Lampung)
}

\author{
Dr. Anuar Sanusi S.E., M.Si \\ Economic and Business Faculty \\ Informatics and Business Institute of Darmajaya Bandar Lampung \\ Email :anuarsanusi@ymail.com
}

\begin{abstract}
The development in economics sector functionally has a strategic position rule in facing the globalization competition challenges because that rule is going to give the work chance and effort in any kind of sectors such as agriculture, forest and plantation, wheel and energy, industry and trade, tourism, transportation and telecommunication, and any others. One of economy resources which have high contribution and also be a priority in global challenges is tourism. Tourism sector is a development sector in economy especially non gasoline and oil which is expected giving big enough contribution toward country economy if it is done optimally (Ramaini,1992 : 99).

The purpose of this research is to serve the concept and first research model in order to increase the societies' perception in introducing variable, knowledge and societies' interest toward tourism in Bandar Lampung and finally to increase the government performance in tourism sectors.

The method in this research used survey technique which focused on questionnaire distributing technique, interview and observation toward academic and profession societies and entrepreneur societies and all societies who live in Bandar Lampung city. The descriptive research result showed that first introducing level and knowledge about tourism was not good enough. Societies Interest and Societies perception variables about tourism sector are good enough. Based on the research result can be concluded that there was a negative significant influence of introducing level and it must be increased. While the dominant factor influenced significantly toward perception variable were knowledge, interest, moderator and others. Analysis test result of Kai quadrate showed that between entrepreneur group, experts, and societies was found the perception differences about tourism sector.
\end{abstract}

Key Words : Perception, Introducing, Knowledge and Interest 


\section{INTRODUCTION}

Economic development as a functional role has a strategic position to face the challenges of globalization competition. The role in the field of economic development has provided employment and business opportunities in various sectors such as agriculture, forestry and plantations, mining and energy, industry and trade, tourism, transportation and telecommunication and so forth. One of the economic resources that have high contributions at once can be a pledge is in line with the global challenges of tourism. The tourism sector is one of development economics sector, particularly for the subject of non-oil sector which is expected to make significant contribution to optimalize the economy of the country (Ramaini, 1992: 99).

Indonesian resources sector can be empowered to the fullest step. Furthermore, through this sector, it also has the potential of human resources towards improving the nation's competitiveness in sustainable development to have a competitive advantage compared to other sectors, as will give proportionately impact (multiplier effect) on the economic and social dynamics in the community. From the potential empowerment impacts (multiplier effect) means that the solution to overcome inequality and poverty can be realized fairly so that people will be more prosperous. In this regard, this sector needs to be recommended to be developed in line with a populist economic empowerment. Economic empowerment can begin with the local residents' empowerment accordance with the spirit of regional autonomy which is one strategy that is intended to develop tourism.

This empowerment is a national strategy that can affect the economic and social dynamics. In order to enhance the role of tourism to support the promotion improvement in the region, it is required a wide range of exelent policies and strategies. Therefore, the tourism sector must be formulated and studied in variety of combinations that starts from combination of regional scope, the components of natural resources / physical / environmental and cultural, marketing components, transportation and infrastructure as well as the scope of the organizational characteristics of public / government, private / private non-governmental organizations, a national company.

To formulate this study, it needs so many inputs from the related parties in tourism. It can be initiated through the introduction level, people's knowledge and interest in the tourism. By knowing the perception, recognition, knowledge and public interest in the tourism, will certainly facilitate the government in their policy formulation and to realize the study of tourism development in their respective regions. Therefore, through this study the writer wanted to examine in more about how the public perception of tourism for the local community in general.

According to this situation, the introduction strategy, knowledge and public interest in tourism should be known as the basis for the formulation of tourism development. It means that the development of tourism has economic and social impact of the dynamical regional economy. Lampung Province as one of many provinces in Indonesia has been awarded by God Almighty the natural resources that can support the regional economy, including the natural beauty that can be harnessed and utilized in the field of tourism. The potential attractions, such as many objects and varieties that reflect the particular areas of Lampung can be developed to be used as objects mainstay in the tourism sector. However, the tourism sector of Bandar Lampung does not have a clear 
strategy and study to be developed. This is because there are many tourism places which have not been maintained to the maximum level, the decline / low growth in visitors from $8.19 \%$ in 2001 to $5.39 \%$ in 2002 (Natural Resources Conservation Center II, 2002), as well as the economic dynamics in tourism places still come seasonal and the public interest is still natural. Similarly, there are also lack infrastructure, the reluctance of investors to invest and the seriousness of the government towards the development of tourism sector.

In this case, the dominant factors that are suspected to be the cause of not maximal management of tourism are as follows: (1) Level of tourism recognition, knowledge and interest in Bandar Lampung is still diverse and natural, (2) Tourism development in Bandar Lampung does not have firm strategy and study, (3) Lack of socialization of tourism spots, and (4) Investors are still not interested to invest in the tourism sector; the tourism businesses are still low, as well as the seriousness of the government to manage the tourism sector.

This study provides for an increased perception of society and its relationship with the level of recognition, knowledge and public interest related to the tourism in Bandar Lampung. Based on the explanation above, it is necessary to study for understanding this matter. Researcher will examine the "STRATEGIC ANALYSIS MODEL OF DETERMINANTS IN MAKING COMPETITIVENESS (Study of Tourism Sector in Bandar Lampung)"

The purposes of this study are as follows;

1) To show the relationship of the level of public recognition of tourism

2) To show the relationship of the level of public knowledge of tourism

3) To indicate the level of public interest in relation to tourism, and

4) To demonstrate the relationship jointly between the recognition rate, and the knowledge of the public interest against the public perception of tourism.

\section{LITERATURE THEORY}

The Definition of Tourism, Tourism essentially is an activity overall rating in the travel or transit with diverse range of motivations that generate demand for goods and services as well as all activities are carried out within government, business areas or tourist destinations in the country through the process of the rise of its influence on economic life, social and cultural development for state and nation (Director General of Tourism, 1988: 3). The definition of tourism above is pure definition of tourism where the traveler aims to spend their spare time on the holidays. Several trips have requirements, as follows: The trip is only for the temporary time; the trip occurs from one place to another, the trip should be related to vacation; those who travel do not work in the location they visit, the traveler aims only for traveling (Oka A Yoeti, 1991: 109). Thus, it can be assumed that the tour is intended to fulfill the desire of knowing the new things, to refresh traveler's mind without the intention of earning income for living or other advantages.

Potential Attractions of Tourism Sector, the potential of tourism in the world has diversity between one place to another place depending on local natural conditions such a topography, flora and fauna, as well as socio-economic circumstances of local 
communities as harmonizing the potential of the attraction (Assisten Dua Kependudukan dan Lingkungan Hidup, 1990: 1)

Natural Attractions of Tourism according to Nyoman S Pandit (1990: 67) are Natural Tourism is a natural attraction of tourism for vacation, resting and recreation in order to restore the physical and spiritual health. Natural Attractions of Tourism usually called Healthy Attractions of Tourism because such places are usually found in the mountains or the coast, as well as the topography has a beautiful view and the water can also have a healthy body weight.

\section{Supporting Facilities Attractions of Tourism}

Environmental Health is a condition that always displays the properties of a clean and healthy, it must be reflected in the clean state of the environment and tourism facilities were neat and clean, the use of the equipment is always well maintained, clean and free of bacteria, healthy food and beverages as well as the appearance of good service (sapta Pesona, 1989: 74).

\section{a. Security}

"Safe is a circumstance condition that gives the warmed feeling for visitors. Safe also means free from fear for the safety of body and soul, possessions. It also means free from threats, disturbances of crimes. Apart from that safe also means or includes the use of infrastructure and facilities which are free of both technical and otherwise, is because of the infrastructure and facilities can be well maintained"(Sapta Pesona, 1989: 73).

\section{b. Transportation}

"Tourism activity depends a lot on transportation and communication because of distance and time factors. Today's transport leads to the growth of tourism very rapid, progress to encourage the advancement of tourism transportation happens expansion in the tourism industry which can create demand for transportation that meets the needs of travelers (Ayoei Oka, 1991: 191).

\section{c. Canteens and Restaurants}

"The field of industrial development can provide new business and employment for the local population, especially for the people who are still bound by a pitch in the agricultural sector (Nursid Sumaatmadja, 1981: 183).

d. Attraction of Tourism for Recreation

Recreation can be very helpful to gain pleasure and satisfaction, restore physical and spiritual health, to develop a clean and positive way of thinking, a new foster morale and productivity growth, foster a sense of solidarity, creating a harmonious atmosphere in the family, and adding a sense of confidence and so on (Joko Purwanto and Helmi, 1994: 28). 


\section{Research Methods and Data Collection Techniques.}

Data Collection of this study uses survey techniques guided on quetioner deployment. This method will be described on the object of study, location of study, the identification of operational research variables, and methods of sampling.

The method will be described in more detail as follows:

1. Research objects of this study are people who live in Bandar Lampung including the community of academic and profession, the business community, and the general public.

2. Research Location Based on the considerations of available time, cost, and power, this research took place in Bandar Lampung.

3. Identification of Operational Variables

In this study the variables that will be analyzed including: (a) Perceptions of tourism as a independent variable (tied); (b) Introduction of tourism as a dependent variable (free);

(c) Knowledge of tourism as a dependent variable (free); and (d) Interest of society as a dependent variable.

\section{Sampling Method}

Sampling Method in this study is a combination of cluster sampling and random sampling that is done by classifying the population into clusters and then classified into smaller category. The steps are following:

Community groups are divided into the business community, the academic community and the profession, and the general public. Random sample was taken from each district through 50 respondents so that the total number of respondents was 200 respondents.

The number of respondents is considered representative for the study sample. Thus, the description of community which become the respondents in this research: 1) The employers Consist of entrepreneurs which are the members of associations, chamber of commerce, HIPMI and GAPENSI as well as the non-association entrepreneurs, 2) Society consists of academics and profession such as State and Private Universities Lecturers and Students, Notary and Doctor, 3) The General Public consists of civil servants, BUMN employees, BUMD employees, private employees, and others, and 4) The Newcomers Community consists of people in Bandar Lampung who stays at Hotels because of there is an activity in Bandar Lampung and then the communities which is in their way to the island of Java or Java to Sumatera.

\section{Method of Data Collection}

Primary Data was obtained from the field research in the form of the data that derived from the respondents in this research. Retrieval of the data through field research using the questionnaire contains a number of questions that must be answered by the respondents.

\section{Methods of Analysis}

Method of Analysis which is used in this research is the analysis of correlation, and Chi Squares that will be described as follows:

\section{Correlation and Regression Analysis}

This analysis aims to look at the relationship between the level of recognition, knowledge and interest in community colleges, the business community, the general public and migrant communities with the public perception of tourism sector. 


\section{Corellation}

This analysis aims to look for feedback relationship (influence) between independent and dependent variables. The formula of this analysis tools;

The Formula:

This method is used to determine the magnitude of relationship recognition, knowledge and interest in the community in tourism sector. By using the multiple correlation formula as follows:

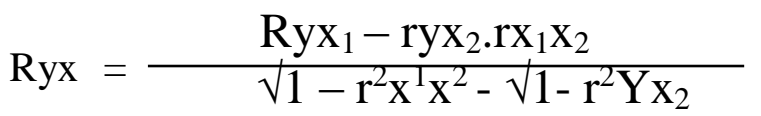

Regression, General Formula:

$$
Y=a+b X_{1}+c X_{2}+d X_{3}
$$

Specification:

$\mathrm{Y} \quad=$ Public Perception of Tourism

$\mathrm{X} 1=$ Level of Public Recognition of Tourism

X2 = Level of Public Knowledge of Tourism

$\mathrm{X} 3=$ Public Interest to Tourism

a $\quad=$ Constant

$\mathrm{b}, \mathrm{c}$ and $\mathrm{d}=$ Regression Coefficient

\section{Chi Squares Analysis}

Analisa ini digunakan untuk melihat perbedaan persepsi masyarakat antara masyarakat pengusaha, masyarakat akademis, masyarakat umum dan masyarakat pendatang terhadap tingkat pengenalan, pengetahuan dan minat tentang pariwisata Dari sampel yang diambil atau dari hasil pengamatan yang dilakukan kemudian dihitung $\mathrm{X}^{2}$ dengan rumus sebagai berikut:

This analysis is used to see the difference between the public perception of the business community, the academic community, the general public and the migrant community on the level of recognition, knowledge and interest about tourism. From the sample of data that was obtained, the observation result is calculated $\mathrm{X}^{2} \mathrm{using}$ the following formula:

$$
X^{2}=\sum \frac{\left(f_{0}-f_{n}\right)^{2}}{-\cdot------~}
$$

\section{Specification:}

fo $\quad=$ Observed Frequency

fn $\quad=$ Expected Frequency 
Test measures - chi square is as follows:

a. Formulating the Hypotheses

b. Specifies the number of categories or rows (r) and alternative or column (k) of the contingency table.

c. Determining the Significant Level (x)

$\mathrm{d}$. Finding the value of observation $(\mathrm{Cij})$ and the expected value $\left(\mathrm{e}_{\mathrm{ij}}\right)$

e. and arranged in a contingency table.

$\mathrm{e}_{\mathrm{ij}}=\left(\mathrm{n}_{\mathrm{j}} / \mathrm{n}_{\mathrm{i}) / \mathrm{n}}\right.$

$e_{i j}=$ Value on the basis of observation $\mathrm{i}$ column $\mathrm{j}$

$e_{i j}=$ The expected value on the basis of $i$ column $j$

$\mathrm{n}_{\mathrm{ij}}=$ Number of observation on the basis $\mathrm{i}$

$\mathrm{n}_{\mathrm{j}}=$ Number of observation in row $\mathrm{j}$

$\mathrm{n}=$ Total number of observations

f. Calculating the value of chi - squared with the formula

$\mathrm{X}^{2}=\sum \Sigma=\left(\mathrm{e}_{\mathrm{ij}}{ }^{-} \mathrm{e}_{\mathrm{ij}}\right)^{2} \mathrm{e}_{\mathrm{ij}}$

g.Looking for X2 value on the distribution table where df $(\mathrm{k}-1)(\mathrm{m}-1)$

h.Determining the conclusion whether accepted or rejected hypothesis with the criteria

- $\quad$ and Ha is rejected, if $X^{2}$ (count) $<X^{2}$ (table), Ho is rejected and Ha is accepted, if $X^{2}$ (count) $>X^{2}$ (table)

- Ho is accepted.

\section{Definition and Operational Variables.}

To avoid wrong interpretation of some terms, it is necessary to explain the terms into operational definition, the perception is driving activity, interpret and provide an assessment of a particular object through the public's view of tourism sector.

a. Introduction is the process of making way to know, or recognize the tourism sector institutions.

b. Knowledge is everything that is known regarding the tourism sector institutions.

c. Interest is that something inside of man which must be filled in order to maintain viability. It is in line with people's need of entertainment through the traveling activity.

d. Perception is the meaning which is connected to the past experience, the received stimulus, the increasing consumption of needs. In other words, perception is a process which includes the activity of sensing, selecting, organizing and interpreting particularly in the field of tourism.

\section{RESULT AND DISCUSSION}

The influence and the relationship of recognition, knowledge and interest of the public perceptions, after processed by using SPSS statistical tools, it was obtained that linear regression equation: $\mathrm{Y}=2,007-8,824 \mathrm{X} 23,38 \mathrm{X} 1+867 \mathrm{X} 3$. From the above regression results, it was indicated that the level of recognition, knowledge and interest of society to public perception has a significant negative relationship between relationship that occurs late introduction to the perception of the community (the public), while between knowledge and interest to the public perception going positive 
relationship. The coefficients of the regression equation turns role in knowledge and interest influence public perception.

\section{First Hypothesis}

First Hypothesis claims that there is a significant relationship between the tourism introductions of the perceptions of the community (the public).

There is a significant influence between tourism introduction and public perception (the public). Tested analysis of hypothesis stated that there is a negative relationship between recognition and perception of society. Based on this hypothesis formulation Zero (H0) and alternative hypothesis ( $\mathrm{Ha})$ is as follows:

H0: There is no positive correlation between the ability of the public service. Ha: There is negative correlation between the introduction of the public perception.

To test a hypothesis based on the value of the $t$ test, if $t$ count $>t$ table $0,05(\mathrm{df}=\mathrm{r}-2)$, then $\mathrm{H} 0$ is rejected. If $\mathrm{t}$ count $<\mathrm{t}$ table 0,10 ( $\mathrm{df}=\mathrm{r}-2)$, so $\mathrm{Ha}$ is accepted. From the results on the table of the appendix, it is obtained $t$ count was -0.48 whereas $t$ table with df $(200-2=198)$ was 1.960 . So t count $-0.48<\mathrm{t}$ table $1.960(198 \mathrm{hp}=1.960)$. Thus, $\mathrm{HO}$ is accepted and $\mathrm{Ha}$ is rejected.

Conclusions drawn from this study that there was indeed a significant negative effect means that the introduction of a factor that is not / determine the perception of the community in Bandar Lampung, or the recognition is not a real problem to improve, this is due to the perception of the public which is still positive determined by other factors such as; knowledge, interest, and other moderators.

\section{Second Hypothesis}

Second hypothesis states that there is a significant relationship between the perception of knowledge and the community (public). The existence and effect of significant relationship between Knowledge and Society Perception (public), tested analysis of the hypothesis states that there is a positive relationship between knowledge and perceptions of the community. Based on this hypothesis formulation Zero (H0) and alternative hypothesis $(\mathrm{Ha})$ is as follows:

H0: There is no positive correlation between the knowledge of the public perceptions.

Ha: There is a positive correlation between the knowledge of the public perceptions. To test a hypothesis based on the value of $t$, if $t$ count $>t$ table $0,05(\mathrm{df}=\mathrm{r}-2)$, then $\mathrm{H} 0$ is rejected. If $\mathrm{t}<\mathrm{t}$ table $12,10(\mathrm{df}=\mathrm{r}-2)$, Ha is accepted. From the results on the table of the appendix, the price obtained $t$ count of 0.899 , while the $t$ table with $\mathrm{df}(200-2=198)$ was 1.960. So t $0.899<\mathrm{t}$ table $1.960(200 \mathrm{hp} \mathrm{=1.960)})$. Thus, $\mathrm{H} 0$ is rejected and $\mathrm{Ha}$ is accepted. Conclusions drawn from this study that there was indeed a significant relationship between the level of one's knowledge and perceptions of the community or tourist perception is strongly influenced by the level of knowledge on Generally and especially for communities in Bandar Lampung. For this test can also be seen through the significant value of 0,37 is $>0,05$ which can be concluded through the significance level that is quite high (under 0:05 that the 95\% confidence level.

\section{Third Hypothesis}

Third hypothesis states that there is a significant relationship and influence between the perceptions of the public interest community (the public). The existence and effect relationship between significant interest and Public Perception (public), tested analysis of the hypothesis states that there is a positive relationship between to people's 
perception of the public interest (public). Based on this hypothesis formulation Zero (H0) and alternative hypothesis (Ha) is as follows:

$\mathrm{H} 0$ : there is no positive correlation between the perceptions of the public interest community

Ha: there is a positive correlation between the perception of the public interest community

From the results on the table of the appendix, the price obtained $t$ count 28,485 , while $t$ table with df $(200-2=198)$ was 1.960 . So $28,485 \mathrm{t}$ count $>\mathrm{t}$ table $1.960(200 \mathrm{hp}=$ 1.960). Thus, $\mathrm{H} 0$ is rejected and Ha accepted. Conclusions drawn from this study that there was indeed a significant relationship between the level of interest in a person and public perception (public) or public perception will be heavily influenced by the tourist's own interest generally, and especially for communities in Bandar Lampung. For this test can also be seen through the significant value of 0,00 is $>0,05$, it can be concluded the significance level is quite high (under 0,05 that the confidence level of $100 \%$ )

\section{Fourth Hypothesis}

Fourth Hypothesis states that there is a significant relationship between influence and recognition, knowledge and public interest in the public perception (the public). An association jointly between the introduction, knowledge and interest in the community (the public) are indicated by simple regression coefficient of determination (model summary). The coefficient of determination R-square (R2) is used to express the magnitude of the variations to how the independent variable $X(x 1, x 2$ dan $x 3)$. The coefficient of determination (R2) lies between $0<\mathrm{R} 2<1$ if: $\mathrm{R} 2=0$, it means the value of the dependent variable that is not influenced at all by the variable (x) and if the value of $\mathrm{R} 2=1$ means that the dependent the variable is affected by the independent variable perfectly.

In this study the results of SPSS displayed R2 (R Square) of 0842. This is an index of determination $\mathrm{R} 2$ is the percentage that accounts for the effect of the introduction of (X1) and knowledge (X2) and interest (x3) to the public perception (y). R2 of 0845 states that the $85 \%$ contribution of the effect of the introduction of (X1), knowledge $(\mathrm{x} 2)$ and public interest $(\mathrm{X} 3)$ on the public perception $(\mathrm{Y})$, while the remaining $15 \%$ $(100 \%-85 \%)$ is influenced by other factors. The fourth hypothesis stated that there was a significant effect relationship together introduction, knowledge and interests with the public perception of (public). The influence of the significant between introduction, Knowledge and Society interest (public) with Public Perceptions, tested analysis of the hypothesis states that there is a positive relationship between the introduction, knowledge and interests with the public perception. Based on this hypothesis formulation Zero (H0) and alternative hypothesis (Ha) is as follows:

$\mathrm{H} 0$ : there is no positive correlation between the introduction, knowledge and interest in the public perception (the public).

Ha: There is a positive correlation between the introduction, knowledge and interest in the public perception (the public).

To test a hypothesis based on the value of $F$, if $F$ count $>F$ table $00,05(\mathrm{df}=\mathrm{r}-2)$, then $\mathrm{H} 0$ is rejected. If $\mathrm{F}$ count $<\mathrm{F}$ table 12,10 ( $\mathrm{df}=\mathrm{r}-2), \mathrm{Ha}$ is accepted. From the results on the table of the appendix, the price obtained F count of 351260 , 
while the F table with df $(200-2=198$ is $1,645.351260$ so F count $>$ F table 1645 (200 $\mathrm{hp}=2.145$ ). Thus, H0 is rejected and Ha is accepted.

Conclusions drawn from this study that there was indeed a relationship and the significant influence of the introduction, knowledge and interest in and perception of society together in the community and especially for the people generally in Bandar Lampung as a research location. For this test can also be seen through the significant value of 0,00 is $>0,05$, it can be concluded the significance level is quite high (under 0,10 that the confidence level of $100 \%$.

\section{Fifth Hypothesis Testing Results}

This Hypothesis states: "There is a big difference in the public perception of belonging to community entrepreneurs, academics and the general level of introduction, knowledge and public interests in tourism sector. Based on the hypothesis, it can be stated that $\mathrm{Nul}(\mathrm{Ho})$ and alternative hypothesis (Ha) as follows;

H0: There is no difference in the public perception of belonging to community entrepreneurs, academics and the general introduction, knowledge and interest in tourism sector.

Ha: There is a difference in the public perception of belonging to community entrepreneurs, academics and the general introduction, knowledge and interest about tourism sector.

The fifth hypothesis performed using analysis techniques of Chi-Square.

Based on Calculations on the table below;

Table 1

Introduction, Knowledge and Interest with Public Perception

\begin{tabular}{|l|c|c|c|c|c|}
\hline \multicolumn{1}{|c|}{ Respondents } & $\begin{array}{c}\text { Observed } \\
\text { Frequency } \\
\left(\mathbf{f}_{\mathbf{o}}\right)\end{array}$ & $\begin{array}{c}\text { Expected } \\
\text { Fraquency } \\
\left(\mathbf{f}_{\mathbf{n}}\right)\end{array}$ & $\left.\mathbf{f}_{\mathbf{o}}-\mathbf{f}_{\mathbf{n}}\right)$ & $\left(\mathbf{f}_{\mathbf{o}}-\mathbf{f}_{\mathbf{n}}\right)^{\mathbf{2}}$ & $\begin{array}{c}\left(\mathbf{f}_{\mathbf{o}}-\mathbf{f}_{\mathbf{n}}\right)^{\mathbf{2}} \\
-- \\
\mathbf{f n}\end{array}$ \\
\hline - Entrepreneur & 60 & 66 & -6 & 36 & 0,55 \\
Community & 70 & 67 & 3 & 9 & 0,13 \\
- Academics & 70 & 67 & 3 & 9 & 0,13 \\
$\begin{array}{l}\text { Community } \\
\text { - Public Community }\end{array}$ & & & & & \\
\hline - Total & $\mathbf{2 0 0}$ & $\mathbf{2 0 0}$ & $\mathbf{0}$ & $\mathbf{5 4}$ & $\mathbf{0 , 8 1}$ \\
\hline
\end{tabular}

Df $=3-1=2$ and $5 \%$ error, then the value of the price obtained by chi square $/ \mathrm{X}$ (square) ${ }^{2}$ tables $=5,591$. Apparently the price of the chi square $/ \mathrm{X}$ (square) ${ }^{2}$ count less than the price of the chi squared table $\left(0.81<5,591\right.$. Due $\left(\mathrm{X}^{2}\right)$ count $<$ of $\left(\mathrm{X}^{2}\right)$ table, then Ho is rejected and Ha accepted. This means that there is the perception of the people belonging to different entrepreneur, academics and public communities against recognition, knowledge and interest on tourism sector. It means that the calculation of the perception the public has the sequence: for people who have a sequence starting from academic, the public has the same response to tourism. Meanwhile, the business community tends to choose more outside traveled in Bandar Lampung and propensity to invest outside of the field of tourism. 


\section{CONCLUSIONS AND SUGGESTION}

\section{Conclusion}

Based on the analysis of this research, it can be concluded as follows:

1. From the analysis of the descriptive level of public recognition is not so good, that is below $50 \%$ of the specified criteria, it is actually based on the above figures can be Easily imagined that the hypothesis is relevant to this research. In other words, the introduction of the public is not so good and good knowledge of the community has almost 75 percent of the specified criteria, it means the better public knowledge about tourism. It is enough for the public interest because although it is still below $75 \%$ of the specified criteria, but it is still approaching it. It is actually based on the figures above are relevant to this research. While the public perception (the public) is very high, because it is above 75 percent of the specified criteria, it is actually based on the above figures have been able to answer the reviews of these hypotheses which is relevant to this research. In other words, the perception of the community (the public) is good enough. Surely that is the bottom-right conclusion on the number of study samples totaling 200 people taken by the sampling process of the population in the community in Bandar Lampung as a research location.

2. The relationship is partial. Conclusions drawn from this study that there was indeed a significant negative effect of the introduction to the perception of the community (the public) in Bandar Lampung, and this time the problem is not too important for the introduction of improved, due to public perception (the public) are still predominantly positively determined by other factors such as; knowledge, interest, and other moderators. The level of one's knowledge and Perceptions of the community (the public) would tour heavily influenced by the level of knowledge on generally and especially for communities in Bandar Lampung. It is shown from the test significance level of 0,05 is quite high at $95 \%$ confidence level. While significant influence of interest and tourist Perceptions of the community will be greatly influenced by general interest itself and especially for communities in Bandar Lampung. This is evidenced from the significant value of the test of $0,00<0,05$ we can conclude the significance level is quite high (under 0:05 that the confidence level of $100 \%$.

3. From the table in the appendix, F count rates obtained at 351260 , while the F table with dk $(200-2=198$ is $1,645.351260$ so F count $>$ F table $1645(200 \mathrm{hp}=2.145)$. Thus, HO is rejected and $\mathrm{Ha}$ is accepted. Conclusions drawn from this study that there was indeed a relationship and the significant influence of the introduction, knowledge and interest in and Perceptions together in public on general and especially for the community as a research Bandar Lampung for this test can also be seen through the significant value of 0,00 is $>0,05$, it can be concluded the significance level is quite high (under 0, 10 is that the confidence level of $100 \%$.

4. Based on the three groups (entrepreneur community, academia and the public), there are differences in the perception of tourism; perception of the different perceptions of the business community and the academic community different from the perception of the general public. 


\section{Suggestions}

Referring to the fourth conclusion above and pay attention to the reality on the ground, the following suggestions should be considered.

1. Introduction, knowledge and interest recommended to be improved through program policies carried out in a planned, purposeful, and sustainable and integrated in order to really have a positive impact on people's perception (the public) in accordance with the expectations and demands of the organization's performance, especially to the local government.

2. Keep formulated a concept of recognition, knowledge and interest in the clearer perception so as not to obscure the understanding recognition, knowledge and interest in the perception of tourism management that has been often used to describe management is ambiguous state apparatus through tourism office though conceptually, the two words it has a different meaning.

3. The results of this study should be followed up with research or study more in-depth and focused in order to formulate a model recognition, knowledge and public interest in the effective performance of the public perception towards the government agency. The results of the study or the study can be used as guidelines in fostering the things that really concerned interests and perceptions of performance in accordance with the expectations of the government organization.

4. All the sector is expected through the policy of the government are guided to support the tourism sector in order to make tourism sector as important product and service in Bandar Lampung.

\section{Bibliography}

As'ad M., 2001, Psikologi Industri, Liberty ; Yogyakarta

Badan Pusat Statistik. 2013. Lampung Dalam Angka, BPS Propinsi Lampung 2011, Pedoman penulisan Skiripsi, Sekolah tinggi Ilmu Ekonomi (STIE) Widya Jayakarta, Jakarta

Gibson, Ivancevich and Donnely, 2007, Organizations, USA, Irwin

Heijrachman dan Suad Husnan, 2006, Manajemen Personalia, BPFE, Yogyakarta

Hasibuan, H. MSP. 2002, Organisasi dan Motivasi, : Dasar Peningkatan Produktivitas, Cetakan ketiga Bumi, Akasara, Jakarta

Indriyo Gitosudarmo dan Agus Mulyono, 2001, Prinsip Dasar Manajemen, BPFE, Yogyakarta

Indriyo Gitosudarmo dan Agus Mulyono, 2001, Teknik Proyeksi Bisnis, BPFE, Yogyakarta

Steers, R.M., 1991, Motivation and Work bahavior, Singapore, Mc. Graw Hill 
Stoner, Freeman, Gilbert, 1995, Management, Ner Jersey, Prentice Hall

Mowen, John, C, and Minor, Michael Alih Bahasa Salim lina, 2002, Perilaku Konsumen (Consummer behavior), jilid I Edisi Kelima, Penerbit Erlangga, Jakarta

Robbin, Stphen P. 1996. Organizational Behavir. 7 th Edition, Prentice Hall. Inc, New Jersey.

Schermerhorn,J.R, Hunt, J.G, dan Obornm Richard N. 1982, Managing Organizational Behavior, Seccond Edition, jhon Wiley dan SOS, Inc. Canada

Suryana, 2006, Kewirausahaan Pedoman Praktis: Kiat dan Proses Menuju Sukses, Penerbit Salemba Empat, Jakarta

Santoso, Singgih dan Tjiptono, Fandy, Riset Pemasaran, Konsep dan Aplikasi dengan SPSS, Penerbit PT Elex Media Komputindo Kelompok Gramedia, Jakarta

Singarimbun, Masri, 2003, Metologi Penelitian, PT. Rineka Cipta, Jakarta

Sugiyono, 2006., Statistika Untuk Penelitian, Penerbit CV Alfabeta, Jakarta

Nazir, M, 2003, Metode Penelitian, Penerbit Ghalia Indonesia

Riduan, 2002, Skala Pengukuran Variabel-Variabel Penelitian, Penerbit ALFABET, Bandung 